\title{
Differences Between Standards Related to Fire Protection Systems Design
}

\author{
RADOJE B. JEVTIĆ, Electrotechnical School , Nikola Tesla“,Niš
}

Review paper

UDC: 699.814

DOI: 10.5937/tehnika2103386J

\begin{abstract}
Fire protection and design of fire protection systems present very important engineering tasks in protection of human lives, animals and material properties. Because of its great significance, everything in fire protection and fire protection systems design must be defined by appropriate standards. There are several different standards in use in different countries around the world. Very often, in solvation of different fire protection tasks, there are many questions asked which standard should be used. There are many similarities between standards, but there are also many differences between standards. Also, some standards don't define at all some cases that can be found in fire protection. This paper was written to present solutions for some particular tasks by some valid standards (EN 54, BS, HПБ 88-2001, VDE 088-2 and NFPA 72) in fire protection and differences between them in the same cases.
\end{abstract}

Key words: standard, design, fire, protection

\section{INTRODUCTION}

Fire protection and fire protection systems design have a priceless importance in everyday human`s life. Fire detection at early stage is one of the most important steps in fire protection. But, there are many questions asked about quality designed fire protection system. What represents the quality designed fire protection system? Does it the system that poses great number of fire detectors, bigger than the number that is predicted by proper standards? Does it the system which fire detectors were optimally positioned? Where to install fire detectors in some special cases? It is very often that these and similar questions can be asked. So, how to proceed in that such situations?

The most correct way is, certainly, that designers do everything what was strictly recommended by valid standard. There are several standards in use around the world for fire protection. Some of the most famous standards are EN 54 (European norms), BS (British Standard), VDE 088-2 (Verband der Elektrotechnikoriginally-Association of German Electrical Engineers, now-Association for Electrical, Electronic \& Information Technologies), NFPA (National Fire Prote ction Association), НПБ 88-2001 (Нормы пожарной

Author's address: Radoje Jevtić, Electrotechnical School „Nikola Tesla“, Niš. Aleksandra Medvedeva 18

e-mail: milan.jvtc@gmail.com

Paper received: 20.04.2021.

Paper accepted: 07.05.2021. безопасности) and other.

Of course, that is also the law obligation of designers. But, this approach, although correct and legal, can produce many practical problems. At the first place, it is because that every potential situation that can be occurred in practice simply cannot be regulated by rules of some valid standards. At the second place, it is because there are no detail defined rules in any standard for any potential situation in reality.

Very typical example for this is the example of corridor. Corridor was defined differently by different standards, so every standard enables rules for installation of fire detectors separately. Also, related to EN 54 (European norms) standard, installation of point heat detectors, line heat detectors, and point smoke detectors below slope roofs is almost non-existent. Related to installation of manual fire detectors, there are differences between NFPA and European standards. There are many other examples for that.

In the situations where the use of different standards is legally and technically possible, there is no strict rule which standard should be used. Also, there is an unwritten rule that designer can use any standard, rule or recommendation that he wants, unless the law demands different. The knowledge of one standard is mostly enough for solvation of many real problems and situations in fire protection, but the knowledge of other valid standards and their comparisons cannot harm in any case. This paper was written to show the 
interpretation of noted five standards for some typical cases that can be encountered in fire protection system design [1-3].

\section{MANUAL CALL POINTS CASE}

These types of fire detectors present obligate parts of stabile installations for fire detection. The work concept of these fire detectors is in closing or opening of current circuit or changing of resistance in current circuit. This is achieved by breaking of cover and pressing of taster. Manual call points must be visually marked with strictly noted purpose and way of turning on. The dimensions of manual call points also must be standardized. The activation of manual call point presents reliable sign of fire detection so, related to that, the time that elapses from the switching on moment till signalisation moment shouldn't be too long.

Usually, manual call points in objects are installed on internal and external sides on walls and constructions. Inside the objects, manual call points can be installed on stairs, exits, evacuation routes etc.

Manual call point presents the simplest device for fire detection so it is logically that rules for its installation be the same or very similar in different standards. This is especially noted for two basic parameters: maximal distance that should be reached to the nearest manual call point (marked as $S$ at figure 1) and the installation height of manual call point (marked as $h$ on figure 2). Also, it is very important to keep in mind that there are also two additional criteria that can influence on two noted criteria: the first criteria is related to the presence of immobile or hard mobile persons in some particular object, while the second criteria is related about increased risk from fire for some particular object.

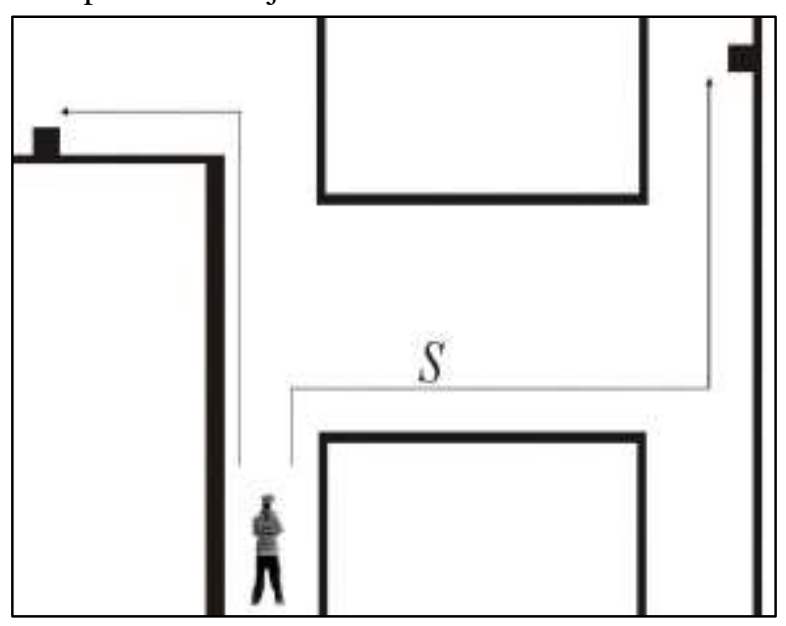

Figure 1 - Parameter that has influence on manual call point installation, related to the maximal distance that should be reached to the nearest manual call point.

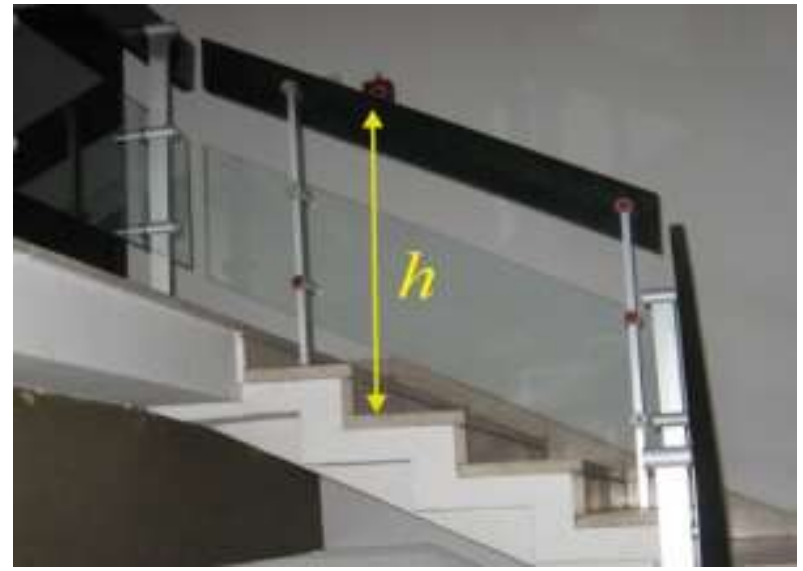

Figure 2 - Parameter that has influence on installation of manual call point, related to the installation height of manual call point.

It would be logical that noted rules to be the same for every standard. But, noted rules are different for different standards.

European standard EN 54-14 (Guidelines for planning, design, installation commissioning, use and maintenance) defines that height of manual call points must be from $1.2 \mathrm{~m}$ to $1.6 \mathrm{~m}$, while the maximal distance should be $30 \mathrm{~m}$. In case of persons with disabilities presence in object, this distance should be reduced.

Related to German standard DIN VDE 0833 (Part 2: Requirements for fire alarm system), it was predicted that manual call point taster should be on height of $1.4 \mathrm{~m}$ with tolerance $\pm 0.2 \mathrm{~m}$, above from the floor level. Concerning the number and arrangement of manual call points inside the object, it should be realised on such way that distance between manual call doesn't exceed $50 \mathrm{~m}$. In the cases related for objects with high fire risk or specific work and technological conditions, noted distance between manual call points should not exceed $30 \mathrm{~m}$.

Installation of manual call points related to British standard BS 5839 (Part 1: Code of practice for system design, installation and servicing) is defined as installation of manual call points in two parts. This standard is the only standard that distinguishes system types for fire detection related to objectives of protection. In case that high fire risk exists or in the case when persons with disabilities presence, the installation height for manual call points should be $1.4 \mathrm{~m}$ and the distance between them should be $30 \mathrm{~m}$. It is very important to note that side viewed area must not be less than $750 \mathrm{~mm}^{2}$. Related to the same standard but different part (Part 6: Code of practice for system design, installation and maintenance of fire detection systems in dwellings) the installation height of manual call point is $1.2 \mathrm{~m}$, while the maximal distance between manual call points should be $45 \mathrm{~m}$. 
Related to Russian standard НПБ 88 (Установки пожаротушения и сигнализации. Нормы и правила проектирования), the position of manual call points should be installed on height of $1.5 \mathrm{~m}$, while the distance between them should be up to $50 \mathrm{~m}$ inside object and $150 \mathrm{~m}$ outside of object. It is also important to note that, related to this standard, manual call points should be installed on at least $0.75 \mathrm{~m}$ distance from other devices or objects.

Related to American standard NFPA 72, manual call points should be installed on height between 42 inches $(1.07 \mathrm{~m})$ and 48 inches $(1.22 \mathrm{~m})$, while their mutual distance shouldn't be over 200 feet $(61 \mathrm{~m})$. Also, this standard defines that manual call point must be far from exit door at least $1.5 \mathrm{~m}$.

It is also important to note that installation of manual call points must be done according to the rules related for humidity protection, mechanical damages, dust etc. $[1-4,8]$.

\section{FLAME DETECTORS CASE}

Flame detectors present special group of fire detectors. These detectors can be applied in situations with fast fire development and when convection products can`t have role in fire detection. That is characteristic for high objects or for objects for flammable materials storage. More precisely, these detectors present the only practical solution. They are especially suitable for hydrocarbon fires detection. The main work principle of these detectors is in detection and measuring of different wave lengths of fire flame.

Related to European standard EN 54-14, there are several different factors that must be consulted in this fire detectors installation. These factors are: direct sight line between flame detector and any point in supervised area, the existence of obstacles that can block radiation and the existence of interfering sources of radiation. There are also and references about false alarming reduction and maximal distances for detection.

Related to German standard DIN VDE 0833, there are similar references concerning flame detectors sensibility reduction with distance. There are also remarks about vibration and humidity (these type of fire detectors can be used in areas where humidity doesn't override $95 \%$ ). The flame detectors must be installed to cover the complete area. Their number depends from local conditions and volume. The installation of flame detector related to optical axis of the detector is presented on figure 3 .

Optical axes of the flame detector should be set to the angle of $45^{\circ}$ relative to the floor or wall. That way of installation enables symmetrical circuit angle of $90^{\circ}$ for monitoring of square that presents monitored room, as it is presented on figure 3 .

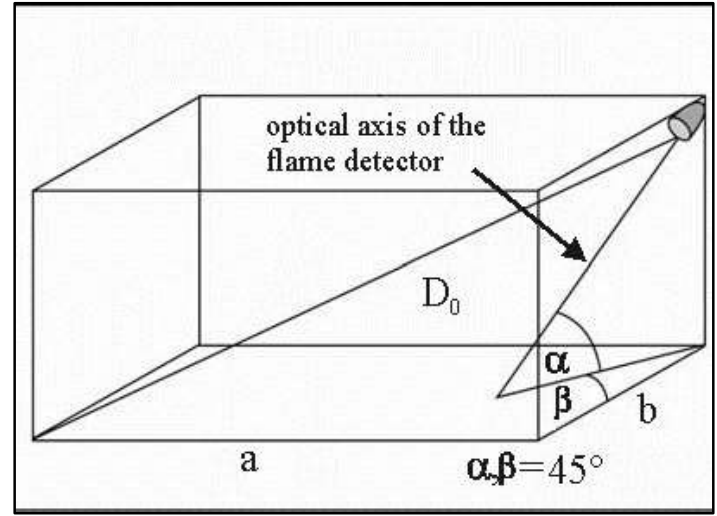

Figure 3 - The installation of flame detector

This standard is not in opposition with European standard, but VDE 0833-2 standard predicts installation of flame detectors on bigger heights with more detail calculation and attention. This standard particularly notes that for heights bigger than $26 \mathrm{~m}$ supervised areas must be defined separately for any case.

Related to British standard BS 5839-1, flame detectors are intended to replace point heat and smoke detectors in rooms with big heights. Also, they are the only solution for fire detection in open space. Maximal distance for these types of detectors should be calculated related to manuals of manufacturers.

Related to Russian standard НПБ 88-2001, it was strictly noted that every protected point must be supervised with at least two detectors, installed one opposite to another. The calculation for supervised area is based on angle of detector's installation and maximal range needed for flame detection. Related to НПБ 72-98 standard, there are four classes of flame detectors, in dependence of maximal ranges needed for flame detection. These maximal ranges were related for TF-5 and TF-6 detection (TF-test fires).

Related to American standard NFPA 72, sensibility of flame detectors is defined by distance along optical axis. But, this standard requires much more criteria for installation of these detectors: detector sensibility, type of combustible material, field of sight for flame detector, response time, presence of other radiation sources, distance of flame detectors etc. [1-3, 8].

\section{LINEAR SMOKE DETECTORS CASE}

The main work principle of these detectors is absorption-the measuring of light attenuation as smoke presence consequence. By construction, these detectors consist of transmitter, receiver and control unit. Their efficiency depends from stratification-the specific appearance when the temperature of smoke and environment temperature are equalized. Because of that reason, the installation height of these detectors can be debatable and many different factors must be analysed and taken into account (ventilation, ambient 
characteristics, height and form of ceiling, volume occupation etc.). There are three different methods for their installation: diagonal installation, horizontal installation at different levels for detection of some smoke layers and horizontal installation in flame peak level. These detectors very often present the only form of protection in rooms with big dimensions and big height.

Related to European standard EN 54-14, covering radius of line smoke detectors is defined on the same way as it was covering radius of point smoke detectors. The special notation of European standard is that in cases of objects without ceiling covering radius of line smoke detector should be $12.5 \%$ of detector`s height above the highest point where fire can be occurred.

Related to German standard DIN VDE 0833-2, the covering radius and detectors distance were differently defined. Covering area noted as $A$ and maximal mutual distance between optical axes of detectors, noted as $2 \mathrm{X} D_{H}$, were defined related to the protected area height, and noted as $R_{H}$, what is presented in table 1 . Recommendation for installation of line smoke detectors below slope roofs are defined by $D_{L}$ in the same table.

Table 1. Height of ceiling, covering area and covering radius related to VDE 0833-2 standard (table source: BlagojevićMĐ. Fire protection systems designing, pp.157)

\begin{tabular}{|l|l|l|l|l|}
\hline \multirow{2}{*}{$\begin{array}{l}\text { Height } \\
R_{H}\end{array}$} & \multirow{2}{*}{$\begin{array}{l}D_{H} \\
{[\mathrm{~m}]}\end{array}$} & \multirow{2}{*}{$\begin{array}{l}\mathrm{A} \\
{\left[\mathrm{m}^{2}\right]}\end{array}$} & \multicolumn{2}{|l|}{ Roof slope } \\
\cline { 4 - 5 } & & $\alpha \leq 20^{\circ}$ & $\alpha>20^{\circ}$ \\
\cline { 4 - 5 } & 6 & 1200 & $\begin{array}{l}0.3 \text { to } \\
0.5\end{array}$ & $\begin{array}{l}0.3 \text { to } \\
0.5\end{array}$ \\
\hline up to 6 & & & $\begin{array}{l}0.4 \text { to } \\
0.7\end{array}$ & $\begin{array}{l}0.4 \text { to } \\
0.9\end{array}$ \\
\hline $\begin{array}{l}\text { between } 6 \text { and } \\
12\end{array}$ & 6.5 & 1300 & $\begin{array}{l}0.6 \text { to } \\
0.9\end{array}$ & $\begin{array}{l}0.8 \text { to } \\
1.2\end{array}$ \\
\hline $\begin{array}{l}\text { between } 12 \text { and } \\
16^{*}\end{array}$ & 7 & 1400 & $\begin{array}{l}0.8 \text { to } \\
1.1\end{array}$ & $\begin{array}{l}1.2 \text { to } \\
1.5\end{array}$ \\
\hline $\begin{array}{l}\text { between } 16 \text { and } \\
20^{* *}\end{array}$ & 7.5 & 1500 & & \\
\hline
\end{tabular}

*-for heights bigger that $12 \mathrm{~m}$, it is recommended to install the second level of line smoke detectors related to ceiling height;

**-allowed, in order to increase detection potential

Related to British standard BS 5839-5 (Part 5: Specification for optical beam detector), the maximal height of line smoke detector installation is $40 \mathrm{~m}$ in special cases and $25 \mathrm{~m}$ in general cases. This standard enables the biggest height of line smoke detectors from all other standards. Related to the first part of the standard, it was recommended to install line smoke detectors as manufacturer's recommendations. It is allowed that optical axis of detector can be installed on distance less the $0.5 \mathrm{~m}$ from the wall. In that case, minimal distance from receiver to transmitter is $3 \mathrm{~m}$, while maximal distance can be $100 \mathrm{~m}$.

Related to Russian standard НПБ 88-2001, the recommendations about line smoke detectors are the same. The differences are related to distances between optical axes of detectors. This distance was particularly defined for heights up to $12 \mathrm{~m}$ and heights from $12 \mathrm{~m}$ to $18 \mathrm{~m}$.

Related to American standard NFPA 72, it is noted that combustion products passes through the optical axis of at least one line smoke detector, no matter where fire occurred. The standard recommendation is that smoke divergence above the fire should be calculated as function of height what line smoke detector installed at. The uniform area of temperature and smoke density development above the fire is spreading by angle of $22^{\circ}$. Because of that, the installation of smoke line detector is recommended exactly in that part, as it is presented on figure 4 [1-3,8].

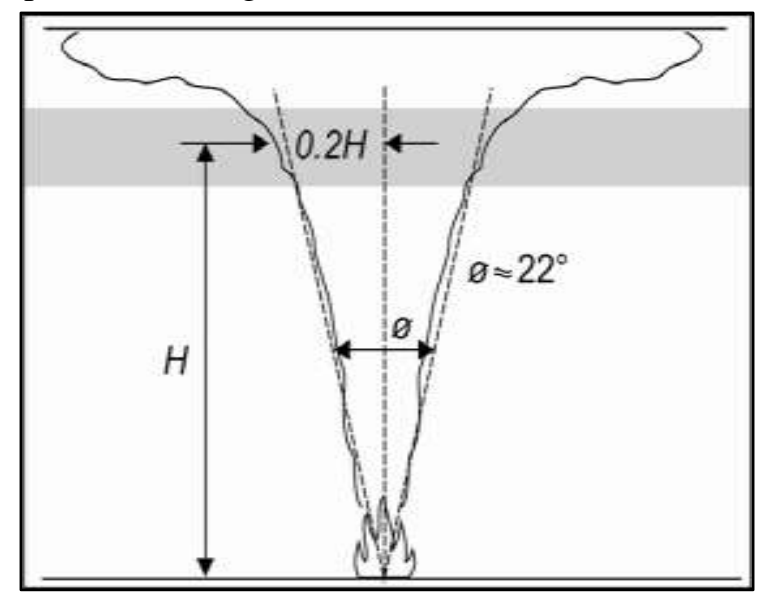

Figure 4 - The smoke spreading (figure source: NFPA 72-2016, Annex B, Figure B.4.9.1)

\section{CORRIDOR CASE}

This case of fire detectors installation in corridors presents one of the most complex cases for fire detectors installation. The main reason for this is in the lack of corridor definition.

Related to European standard EN 54-14, there are no special references except distance of detector from the wall.

Rules for these problems are more precise in German standard DIN VDE 0833-2 than in European EN 54-14 standard. This standard defines corridor as room which is narrower than $3 \mathrm{~m}$ and gives maximal distances between smoke and heat fire detectors.

Related to Related to British standard BS 5839-1, rules are different because the corridor is defined as room with $5 \mathrm{~m}$ width.

Russian standard НПБ 88 only gives correction related to point smoke detectors. Related to this, 
maximal distance between point smoke detectors can be increased for 1.5 times in rooms up to $3 \mathrm{~m}$ width.

The most detailed rules for installation of point smoke and heat detectors were given in American NFPA 72. This standard defines corridor as room up to $4.6 \mathrm{~m}$ width. The distance between detectors is defined related to maximal detector's covering area. The arrangements of smoke detectors in corridor related to different standards are presented on figure 5 [3,5-9].

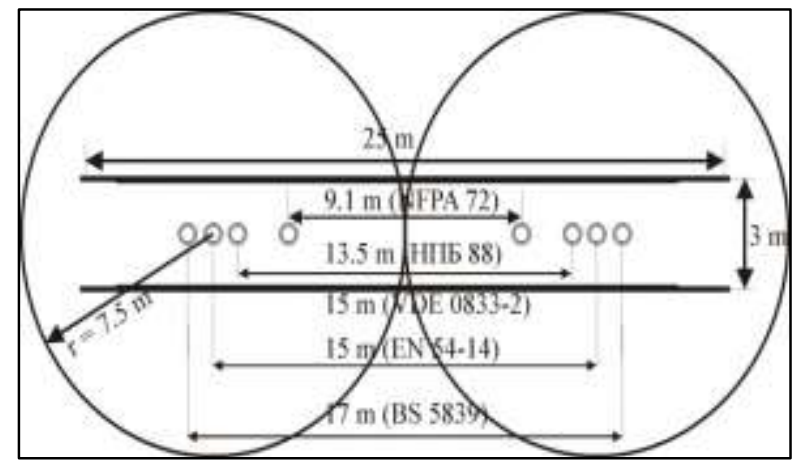

Figure 5 - The arrangement of smoke detectors in corridor related to different standards.

\section{SOUND SIGNALISATION CASE}

Sound and visual signalisation presents very important and obligatory parts of fire detection systems.

Related to European standard EN 54-14, there were no special rules for installation and arrangement for sound alarming devices. This standard defines two types of sound devices: type noted as A for alarming inside the object and type noted as B for alarming outside. However, it is recommended that the lowest sound level for these devices should be $65 \mathrm{~dB}(\mathrm{~A})$ or 5 $\mathrm{dB}(\mathrm{A})$ above any potential noise level that can be occurred in ambient longer than 30 seconds. Maximal sound level should be up to $120 \mathrm{~dB}$ (A), while the frequency range should be from $500 \mathrm{~Hz}$ to $2000 \mathrm{~Hz}$. In the bedrooms, recommended sound level should be 75 $\mathrm{dB}(\mathrm{A})$, while in the rooms with noise recommended sound level should be 95 (A).

Related to German standard VDE 0833-2, rules for sound level and frequency for alarming devices were similarly defined as for EN54-14 standard. It was recommended that sound level should be at least $10 \mathrm{~dB}$ (A) higher from ambient sound level. Also, this standard noted that in cases of persons with sound disabilities, visual and vibration devices must be predicted.

Related to British standard BS 5839-1, frequency range from $500 \mathrm{~Hz}$ to $8000 \mathrm{~Hz}$ is range that human ear is especially sensitive for. Of course, human ear sensibility decreases with ages. For higher frequencies, the sound attenuation is greater because of obstacles, so standard recommends frequency range from $500 \mathrm{~Hz}$ to $1000 \mathrm{~Hz}$.
Related to Russian standard НПБ 88-2001, the only thing that it was noted is that alarm sound signal should be different from other types of sound alarms by level and frequency. Detailed rules were noted in ГОСТ 26342-84 Средства охранной, пожарной и охранно-пожарной сигнализации. Типы, основные параметры и размеры standard. Related to this standard, the sound alarm volume must not be below $85 \mathrm{~dB}(\mathrm{~A})$ at range of $1 \mathrm{~m}$.

Related to American standard NFPA 72, rules for sound alarming were detailed analysed. Basic sound level above ambient sound level should be $15 \mathrm{~dB}(\mathrm{~A})$, for public rooms and $10 \mathrm{~dB}(\mathrm{~A})$ for private residential objects, at height on $1.5 \mathrm{~m}$ above floor level. For bedrooms, recommendation of this standard is the same as recommendation for EN standard. This recommendation is $75 \mathrm{~dB}(\mathrm{~A})$ at "pillow" level. It is specially noted that in rooms with ambient noise above $105 \mathrm{~dB}(\mathrm{~A})$, visual signalisation should be used. It is because the maximal level of sound alarming related to this standard is $110 \mathrm{~dB}(\mathrm{~A})$. This standard also presents some average sound levels for some specific rooms, such as offices (55 dB (A)), industry rooms $(80 \mathrm{~dB}$ (A)), workshops ( $85 \mathrm{~dB}(\mathrm{~A})$ ) etc.

It is interesting to note that none of five noted standards analysed in this paper don't define rules for installation and arrangement of sound alarm devices [3].

\section{VISUAL SIGNALISATION CASE}

These systems at the first step enable faster orientation in supervised area. Visual signalisation can be realized by: parallel indicators, synoptic tables with graphical presentation, graphic visualisation on monitors and different flashing lights.

Related to European standard EN 54-14, visual signalisation presents addition to sound signalisation and is not installed independently. The part of this standard which is deals whit visual signalisation is EN 54-23. This part precisely notes specification for illumination and defines three categories of devices, in dependence of installation location. Device that can be installed on ceiling is marked as $\mathrm{C}$, device that can be installed on wall is marked as $\mathrm{W}$ and device that can be installed anywhere (so called free device category) is marked as $\mathrm{O}$. Very important note is to paid attention on hallways, corridors, wall partitions and similar that can significantly increase visual alarming effects. In the cases where flashes are used, the frequency of flashes should be between $0.5 \mathrm{~Hz}$ and $2 \mathrm{~Hz}$, what purports 30 and 120 cycles per minute.

Rules of German standard VDE 0833-2 for these problems are completely the same as in European EN 54-14 standard. 
Related to British standard BS 5839-1, visual alarm installation can be used in rooms where ambient sound level exceeds $90 \mathrm{~dB}(\mathrm{~A})$, as addition to sound alarm installation. Installation details were not noted. Minimal height for installation of visual alarm device is recommended to be $2.1 \mathrm{~m}$.

Russian standard НПБ 77-98 Технические средства оповещения и управления эвакуацией пожарные. Общие технические требования. Методы испытаний defines rules for visual signalisation. Installation height was not defined by this standard. Other important characteristics were presented in ГОСТ 12.4.026-76 Цвета сигнальные и знаки безопасности standard.

American standard NFPA 72 has detailed rules for visual signalisation. Very precisely, flashing frequency, installation locations, light intensity, minimal distance for alarming and other important factors were given. Device must be located on the wall on the height between 2.03 and $2.44 \mathrm{~m}$ above the floor. In the cases when the ceiling is lower then allowed, device must be located at least $15 \mathrm{~cm}$ below the ceiling [3].

\section{CONCLUSION}

Noted examples showed differences between different standards for one particular case. Of course, the limits of this paper didn't allow presentation of all possible cases with all differences between standards: fire detectors arrangement in rooms with no standard geometry, fire detectors arrangement on roof with more slopes, fire detectors arrangement on flat ceiling with girts, fire detectors arrangement in ceiling in the form of honeycomb, fire detectors arrangement in double or perforated ceiling etc. Some of these examples are presented from figure 6 to 8 .

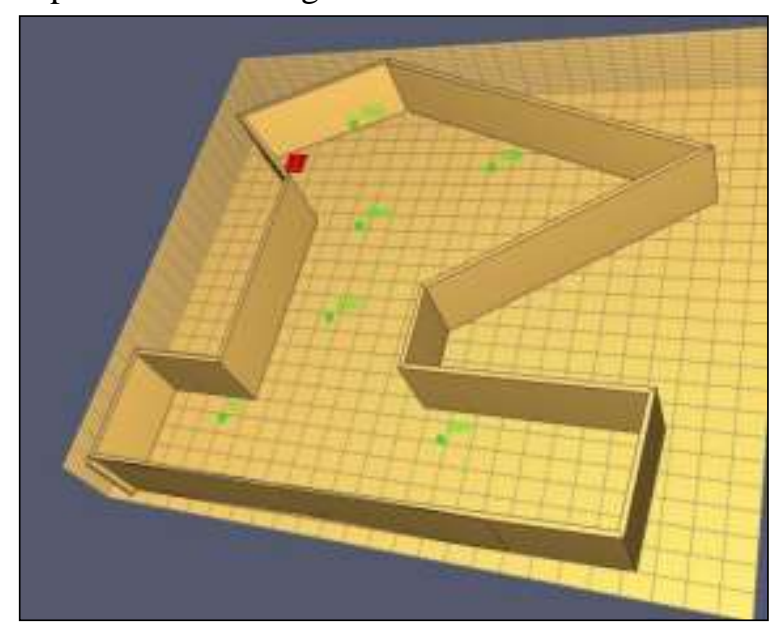

Figure 6 - Fire detectors arrangement in room with no standard geometry in FDS simulation software (figure source: Jevtić R. B. The fire detectors arrangement in rooms with no standard geometgry, Safety Engineering, 2016)

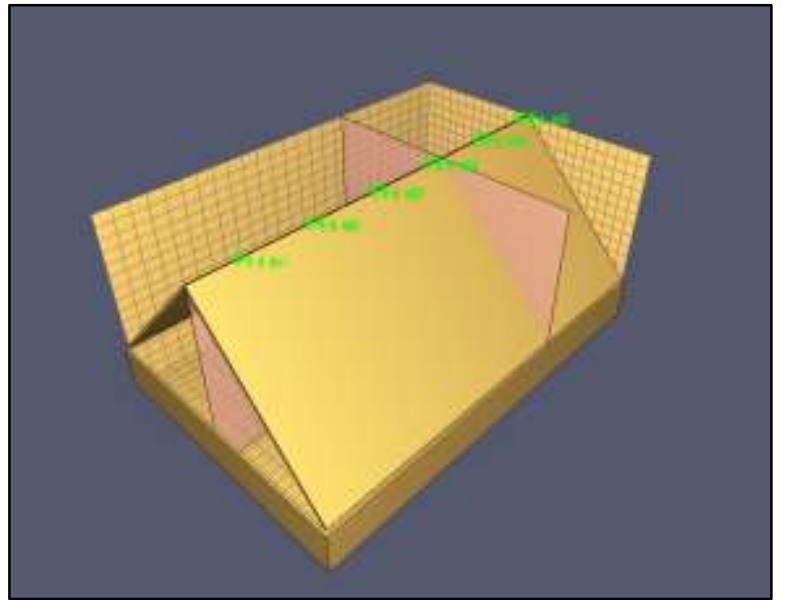

Figure 7 - Fire detectors arrangement in (figure source: Jevtić R. B, Blagojević M. Đ. Point Fire Detectors Arrangement in Special Cases-The slope Roofs case, Int. Journal of Engineering Research and Application, 2018)

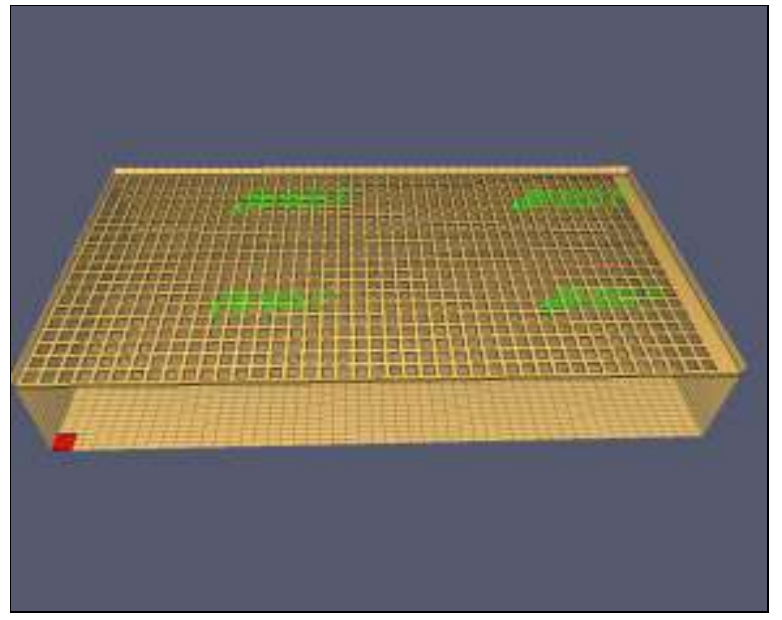

Figure 8 - Fire detectors arrangement in room with perforated ceiling in FDS simulation software (Smoke spreading simulation in double (perforated) ceilings, Vatrogaštvo i upravljanje požarima, 2017)

It is known that European standard presents obligate standard in most of European countries. German standard is almost the same as European standard, but, in some cases, this standard enables more precise and more detailed references than European standard. British standard is more complicated for appliance. The reason for this lies in the fact that this standard presents the only standard that classifies systems related to persons protection or/and properties protection (Life systems types, Property systems types etc.). This standard also enables solutions and references for cases and situations that are not mentioned in European standard. Related to other standards, Russian standard presents the most restrictive standard. American standard presents the most detailed and the most precise standard related to other standards. This standard 
demands advantage knowledge about fire from designer [10-12].

Generally, what should be the main reference for designers of these systems? Legal and professional obligation for every designer is to strictly follow valid standard. But, in cases where valid standard doesn't cover some particular case, it is good to have an insight in potential solutions in other standards. So, designers are free to use any reference they think is appropriate, without deviation from valid standard (for example, for designers in Serbia it is European standard).

\section{REFERENCES}

[1] Blagojević M. Đ, Alarm systems, Faculty of occupational safety, Niš, pp. 4, 59-61, 94-98, 101110, 184, 2011.

[2] Blagojević M. Đ, Alarm systems, Faculty of occupational safety in Niš, ISBN 978-86-6093-0257, pp.4-6, 78-81, 114-116, 121-131, 223, Niš, 2015.

[3] Blagojević M. Đ, Fire protection systems designing, AGM Book, ISBN 978-86-86363-89-3, Beograd, pp. $1-6,83-88,112-121,159-167,194-196,198-201$, 2018.

[4] Glavinić P, Rasković Đ, Manual for preparation of candidats for professional exam from fire protection field, Meritus tim, ISBN 978-86-917589-91, Fourth edition, pp. 419-423, Beograd, 2016.

[5] Jevtić R. B, Airflow Influence on Smoke Detectors Arrangement in Corridors, Scientific Technical Review, ISSN: 1820-0206, Vol. 69, No. 3, pp. 30-34, DOI: $10.5937 / \mathrm{str} 1903030 J, \quad$ UDK: 662.767.55; 621.376.23:541.182.3, Belgrade, Serbia, 2019.

[6] Blagojević M, Jevtić R, Ristić D, Comparative Analysis Of Rules For Smoke Detectors Placement In
Five Leading Standards, 18 International Conference Man \& Working Environment, Faculty of Occupational safety in Niš, Niš, Serbia, 06.- 07.12.2018.

[7] Jevtić RB. Comparative Simulation Results for EN54, НПБ 88 and NFPA 72 Standards-the Hallway Case, Int. Journal of Engineering Research and Application, ISSN 2248-9622, Vol. 7, Issue 12, (Part-2) pp.62-70, December 2017.

[8] Blagojević M, Jevtić R, Ristić D. Comparative analysis of rules for fire detectors arrangement and distributions in five standards, Осма научна конференция с международно участие „Гражданската безопасност 2017“, Sofia, Bulgaria, 6-7. 04.2017.

[9] Jevtić R. B, Blagojević M, Smoke and Heat Detectors Arrangement in Hallways, Safety Engineering, Vol 7, No. 2, pp. 21-26, ISSN-2217-7124, Niš, Serbia, 2017.

[10]Blagojević M, Jevtić R. and Ristić D, Comparative analysis of rules in five leading standards for smoke detectors siting in the presence of a ceiling irregularity, Transactions of the VSB - Technical university of Ostrava, DOI 10.1515/tvsbses-2017-0011, Vol. XII, No. 2, pp. 23-29, 2017.

[11]Jevtić R. B, Blagojević M. Đ. Point Fire Detectors Arrangement in Special Cases-The slope Roofs case, Int. Journal of Engineering Research and Application, ISSN 2248-9622, Vol. 8, Issue 3, (Part-3) pp. 21-27, March 2018.

[12]Jevtić R, Blagojević M, Special cases in point fire detectors arrangement - roofs with more slopes, 18 International Conference Man \& Working Environment, Faculty of Occupational safety in Niš, Niš, Serbia, 06.-07.12.2018.

\section{REZIME}

\section{RAZLIKE IZMEĐU STANDARDA KOJI SE ODNOSE NA PROJEKTOVANJE SISTEMA ZAŠTITE OD POŽARA}

Zaštita od požara i projektovanje sistema za zaštitu od požara predstavljaju veoma vazan inženjerijski zadatak u zaštiti ljudskih života, životinja i materijalnih vrednosti. Zbog ovako velikog značaja, sve što je vezano za zaštitu od požara i projektovanje sistema za zaštitu od požara mora biti definisano odgovarajućim standardima. Postoji nekoliko različitih standarda u upotrebi u različitim zemljama širom sveta. Veoma često, u rešavanju nekog zadatka vezanog za zaštitu od požara, postoje mnoga pitanja koji standard treba upotrebiti. Postoje mnoge sličnosti ali takođe i mnoge razlike među standardima. Takođe, neki standardi uopšte ne definišu neke slučajeve koji se mogu javiti u zaštiti od požara. Ovaj rad je napisan da predstavi neka rešenja za nekoliko različitih slučajeva od strane nekoliko validnih standarda (EN 54, BS, НПБ 88-2001, VDE 088-2 i NFPA) u zaštiti od požara i razlike između njih.

Ključne reči: standard, projektovanje, požar, zaštita 